\title{
Review \\ Leadership in Precarious Contexts: Studying Political Leaders after the Global Financial Crisis
}

\author{
Cristine de Clercy * and Peter A. Ferguson \\ Department of Political Science, Western University, London, N6A 5C2, Canada; E-Mails: c.declercy@uwo.ca (C.d.C.), \\ p.ferguson@uwo.ca (P.A.F.)
}

Submitted: 2 February 2016 | Accepted: 16 May 2016 | Published: 23 June 2016

\begin{abstract}
A series of crises and traumatic events, such as the $9 / 11$ attacks and the 2008 global financial crisis, seem to have influenced the environment within which modern political leaders act. We explore the scholarly literature on political leadership and crisis since 2008 to evaluate what sorts of questions are being engaged, and identify some new lines of inquiry. We find several scholars are contributing much insight from the perspective of leadership and crisis management. Several analysts are investigating the politics of crisis from a decentralist perspective, focusing on local leadership in response to challenging events. As well, studying how citizens interpret, respond to, or resist leaders' signals is a developing area of inquiry. While our study reveals some debate about the nature of crisis, and whether the context has changed significantly, most of the scholarship reviewed here holds modern politicians face large challenges in exercising leadership within precarious contexts.
\end{abstract}

\section{Keywords}

complexity; elites; global financial crisis; leaders; leadership; leadership literature; political leadership; risk; uncertainty

\section{Issue}

This review is part of the issue "New Approaches to Political Leadership", edited by Mark Bennister (Canterbury Christ Church University, UK).

(C) 2016 by the authors; licensee Cogitatio (Lisbon, Portugal). This article is licensed under a Creative Commons Attribution 4.0 International License (CC BY).

\section{Introduction}

The last several years have witnessed a welcome resurgence in the analysis of political leaders and the exercise of leadership. From studies of governance occurring in small municipalities to agency analyses within supranational structures, many new works are reinvigorating this research area. The literature reaches back to the earliest period of recorded history because, since the beginnings of social life, people have taken leadership roles within groups. However, while the phenomenon of leadership always is present in societies, we know that how leaders lead is changeable. Our understanding of leadership and its evaluation necessarily is grounded in our times and our context. The socio-economic environment within which people lead is a prime determinant of how leaders must act to be effective, and how we adjudicate effective leadership.
This environment has been subject to several significant shocks and crisis events over the last fifteen years.

The leadership environment certainly was influenced by the 2007-2008 global financial crisis (GFC), where a complex interplay of lax financial policies and risky lending practices precipitated the worst financial collapse since the Great Depression. Economic growth declined sharply in many states; most governments were forced to take unusual actions to ensure credit liquidity, bolster trade and reassure nervous populations. Importantly, the GFC's effects have not been treated as an isolated set of incidents that were manageable at the margins of the world's political systems. Rather, this economic crisis is prominent among a series of many unfortunate events including terrorist attacks and natural disasters whose net effect seems to have pushed crisis management toward the top of leaders' agendas. 
Along with the frequency of recent crisis events, modern political leaders also face several other destabilizing pressures. Massive technological change, the power of social media and the interconnectedness of globalizing markets likely exacerbate the challenge of managing instability. Precisely because political leadership sits at the heart of how we try to understand and explain the functioning of political systems, there seems to be a concerted effort toward exploring how political elites might exercise leadership in contexts marked by change and instability. This shift in scholarship is adding new information and understanding to an understudied area of leadership analysis: how leaders lead in crisis contexts. This burgeoning literature on political leadership draws from several areas of social science, strategic studies and management studies. Authors located in the Netherlands, Great Britain, the United States, Australia, Germany, Sweden and other places have contributed some important studies within the last several years. However, the literature's development since the global financial crisis peaked in 2008 has not been seriously explored. So this paper aims to trace the development of the literature concerning political leadership and crisis in the post-GFC era, note its merits and limitations, and mark some of the more promising lines of inquiry.

\section{Leadership in Precarious Contexts}

In our introductory comments we touched on some of the key events that seem to have altered the context of modern political leadership and so shaped how it is being studied. It is worth briefly considering the literature's characteristics before proceeding to locate and explore the approaches under study here. Prior to the terrorist attacks of September 11, 2001 there were not many mainstream political scientists who focused explicitly and consistently on understanding how politicians exercise leadership in contexts marked by instability, ambiguity or crisis. Following James McGregor Burns' approach in his foundational work, leadership often was considered as the consequence of an "array of political motives applied to a structure of political opportunity"(Burns, 1978, p. 105). Rare indeed were texts that studiously investigated how politicians operate in conditions of uncertainty or ambiguity. Unlike colleagues in political economy who consciously and methodically incorporated these elements into their models, most political scientists tended to consider how leaders led in stable, routinized environments (Knight, 1971; Mueller, 2001). Of course, a few works such as Graeme Allison's classic study The Essence of Decision probed how leaders and bureaucracies produce decisions within crisis contexts (Allison, 1971), and some analysts such as F.G. Bailey and Murray Edelman explored how leaders might bend informational ambiguity or situational uncertainty to their ends
(Bailey, 1988; Edelman, 1988). In analyses of individual leaders, a handful of scholars such as Alistair Cole and Robert Elgie carefully focused on how leaders approach decision-making in unstable environments or crisis periods (Cole, 1994; Elgie, 1993). Such studies, however, by far were the exception rather than the rule.

The fall of the World Trade Center Towers in 2001 was the first of a series of traumatic events that have occurred over the last fifteen years. In 2004 the Madrid train bombings were a particularly deadly attack that occurred mere days before general elections in Spain. Hurricane Katrina, the costliest natural disaster in the history of the United States, struck in the summer of 2005. It revealed governmental chaos and widespread disorganization in coordinating emergency response resources. In April of 2010, a volcano eruption in Iceland sent a giant ash cloud several miles into the atmosphere, crippling European aviation and stranding 10.5 million passengers (Kuipers \& Boin, 2015, pp. 196197). A massive earthquake and tsunami struck Japan in March of 2011, disabling one of the world's largest nuclear power stations and mobilizing deep public anxiety about nuclear power in many other states such as Germany and Italy. The Fukuyama Daiichi nuclear crisis focused the world's attention on key questions of governmental transparency, public accountability and emergency management capacity.

The brief review of several traumatic events that occurred since 2001 helps to explain why there is renewed interest in studying the role of governments in managing such crises and the responsibility of leaders to their publics. One of the main treatments exploring how leaders and public administrators ought to understand and manage crisis events was Arjen Boin, Paul 't Hart, Eric Stern and Bengt Sundelius' 2005 study, The Politics of Crisis Management: Public Leadership Under Pressure (Boin, 't Hart, Stern, \& Sundelius, 2005). While administrative studies of emergency management measures was an established literature long before 9/11, Boin et al.'s book was among the first new treatments to connect this literature with the core questions of political leadership. Its basic argumentthat crisis management had become a defining feature of contemporary governance-was taken up and explored in several later works such as Governing After Crises: The Politics of Investigation, Accountability and Learning (Boin, McConnell, \& 't Hart, 2008).

The arrival of the global financial crisis and its aftershocks in the form of associated events like the 2008 riots in Greece and the 2009 Euro zone crisis simply further demonstrated that disorder seemed to be a hallmark of the new world order. The GFC began in 2006 with a decline in housing prices in several southern US states. Eventually the US mortgage market collapsed, along with sharp international declines in real estate valuation, firm failures, runs on banks and intervention by the International Monetary Fund (IMF) in Iceland and 
Ireland. Oliver Blanchard, an IMF economist, estimated that the total losses caused by the GFC exceed $\$ 4,700$ billion (Hindmoor \& McConnell, 2013, p. 543).

The GFC had large negative effects on most western economies and its influence was broadly distributed across states and regimes. Part of the public's reaction to the GFC was found in the widespread perplexity that modern economic systems are so intertwined, and so vulnerable to relatively sudden dislocation. The recession initiated in 2008 proved to be a difficult period for governments to address in terms of how to reassure nervous publics, calm investors, encourage growth and moderate deficits. At the time of writing, many governments continue to hope the end of this period is at hand, as they search for a path toward economic stability. For scholars, the GFC provides an opportunity to examine whether and, if so, how analysts are approaching the role of crisis in the exercise of power. If we understand modern governance to take place in a perennially fraught environment (as some people do), then are we studying the interplay between political elites, their entourages, experts and citizens with respect to crisis management? If this is under consideration, how are we approaching crisis leadership?

\section{The Study of Political Leadership and Crisis since 2008}

To survey how political leadership is being studied since 2008, we identified recent work published from January of 2009 to December of 2015. In part owing to our mission to understand how the literature has developed over the last eight years or so, and because monographs can require much production time, the focus is on scholarly articles. We used two search methods in particular to identify suitable works. First we searched the Thomson Reuters Web of Science database. This database is particularly helpful because it concentrates on peer-reviewed scientific publications, and largely excludes single-authored books and edited essay collections. Indeed, its promoters claim it is the world's largest collection of research publications (Thomson Reuters, 2016). As well, we also searched the Google Scholar database, as it is a leading source for scholarly publication and captures some publications that are not collected by the Web of Science. There are a wide variety of studies within the general category of "leadership". However, many of these concern issues beyond our specific interests, such as studies measuring social relationships in music ensembles, or how to use literacy coaching to support inner city high school teachers. Using English-language parameters we narrowed our search and looked specifically for scholarly articles with the words "political leadership" and "crisis" as topics. This strategy generated the location of most of the texts under discussion below.

We then parsed the search results to identify the sorts of studies that are the focus of our attention. Because we wanted to consider political leadership, rather than other kinds, we concentrated on publications located within the social science areas of government and law, and within the core disciplinary journals. This search strategy identified 81 relevant articles. Because we're interested in the active scholarship concerning crisis leadership, we then excluded works shorter than ten pages in length, and some that clearly concerned other fields of inquiry such as health policy research. So we were left with 54 English-language journal articles concerning political leadership and crisis. A reviewer kindly directed out attention toward one additional study. We accessed this set of 55 papers and read them with view toward identifying some main approaches and common areas of interest. As a product of this additional scrutiny, the set of papers under study was further narrowed. Owing to the significant size of the literature and the balance of its content, below we discuss three distinct approaches to studying crisis leadership that are common ones within our literature collection, rather than creating an exhaustive accounting of all the individual works. Thus we examine 26 scholarly papers published in 25 journals from January of 2009 to December of 2015.

Our search suggests the subject of how political leaders engaged a specific crisis is a relatively common research focus. Since 2008, and in the context of the conclusion of the global financial crisis, researchers actively have been engaging crisis leadership. As stated above, in light of the many crises that have beset public leaders in recent years, we expected that there would be at least some minimal treatment of this topic in newly published research. Our group of studies may be divided further into three sorts: studies that approach crisis leadership from a centralist perspective; those that approach crisis leadership from a decentralist perspective; and those focusing on followership. We begin with a review of the first grouping of centralist approaches in part because it is by far the largest set of studies within our search results, and also because it provides a helpful contrast to the other groupings as discussed below.

\subsection{Centralist Perspectives on Crisis Leadership: The Boin-'t Hart-McConnell School}

Within our set of leadership studies we noticed that a significant number of authors adopted a centralist approach. This is to say that generally these authors examined crises at the national level, and by means of focusing on how leaders at the political center managed crises strategically. As mentioned above, the 2005 text by Arjen Boin, Paul 't Hart, Eric Stern and Bengt Sundelius was an important study. One of its most helpful insights is the overarching assertion that crises are political at heart (Boin et al., 2005, p. ix). For leadership 
scholars, The Politics of Crisis Management: Public Leadership Under Pressure was innovative because it married some traditional, centralist perspectives found in the crisis management literature to some of the core questions within the political leadership literature. It bridged the two literatures, and revealed several ways in which the discussions of crisis management and effective public leadership could enrich each other. Our search for new works on crisis and political leadership uncovered several studies by some of these same authors. Owing to the role of Boin, 't Hart and McConnell in particular in terms of working as a team as well as in co-authoring with other colleagues, and in view of the scope of their contributions and their analytical consistency, here we refer to this scholarship cluster as the Boin-'t Hart-McConnell School.

Toward identifying the new work on crisis leadership that has appeared since the GFC, in January of 2009 an article titled "Crisis Exploitation: Political and Policy Impacts of Framing Contests" appeared in the Journal of European Public Policy (Boin, 't Hart, \& McConnell, 2009). Boin, 't Hart and McConnell built on some earlier work on the framing of crises, and here approached crises as an exercise in blame management. They observed crises often produce change as a consequence of destabilizing power and authority relationships. However, it is difficult to predict with any certainty how changes will unfold. Relying on fifteen indepth cases studies, the article attempted to formulate a theory of crisis exploitation, which is defined as the "purposeful utilization of crisis-type rhetoric to significantly alter levels of political support for public officeholders and public policies" (Boin et al., 2009, p. 83). The authors concluded that crisis exploitation strategies matter. Political incumbents are likely to survive the political game of crisis exploitation if they start out with a good stock of political capital, cogently communicate their framing of the crisis, have not held office for very long, and benefit from the perception that the cause of the crisis is exogenous. As well, they noted it may be advantageous to have an expert commission as the main locus of inquiry about the crisis (Boin et al., 2009, p. 100).

This line of inquiry was supplemented a year later with another study of the politics of blame. Boin, Preston, ' $\mathrm{t}$ Hart, and McConnell noted much attention traditionally has been paid to the "acute response" phase of crises, where critical decisions are made and communicated to frightened publics (Boin, Preston, 't Hart, \& McConnell, 2010, p. 706). However, the post-crisis phase, or the "crisis after the crisis", increasingly is marked by intense politicization. In a single-case study of the Hurricane Katrina crisis, Boin et al. (2010) took a new tack and focused on evaluating to what degree a politician's personal leadership style explains the outcomes of crisis-induced blame games. They concluded President George W. Bush's leadership style was ill fit- ted to the sort of crisis he tried to manage. As well, his past decisions in the form of patronage appointments to key emergency management posts along with his proclivity to not change course despite political criticism all combined to exacerbate the public's perception of leadership failure (Boin et al., 2010, p. 720).

Alongside these analyses of blame shifting and crisis, another strand of research began to surface. Building on two articles in 2008 and 2009 co-authored with Mark Rhinard on the European Union's role in managing transboundary threats and building transnational crisis management capacity, Boin introduced a new sort of crisis (Boin \& Rhinhard, 2008; Rhinhard \& Boin, 2009). Crafted as the introduction to a special issue of the Review of Policy Research, Boin's essay is titled "The New World of Crises and Crisis Management: Implications for Policymaking and Research". He argued that the world of crises and disasters is shifting, and such change presented new challenges to politicaladministrative elites as well as researchers (Boin, 2009, p. 367). A sketch of a theoretical ideal-type of the modern crisis is presented.

This new type, which he termed a transboundary crisis, is founded upon the traditional notion of crisis and its three core concepts of threat, urgency and uncertainty. However, transboundary crises are different because they emanate from the "tightly woven web" of critical infrastructures that characterize modern society and they can easily cross geographical borders (Boin, 2009, p. 368). He suggested as well that transboundary crises also may jump across functional and productive systems, such as moving from the auto production system to the credit system, as well across time. Unlike normal crises which have clear beginning and end points, Boin argued these new types of crises cannot be pinpointed in time because their roots are found deep within social systems and their effects may not be perceived for several years. Owing to their quick mobility, systemic depth and geographical breadth, political authorities face many challenges in deciding who ought to take responsibility for these events and also in appreciating the significant damage potential such episodes represent (Boin, 2009, pp. 368-369).

This new thinking about the nature of transboundary crises was advanced in 2014 with the publication of an additional research paper. Arjen Boin, Mark Rhinard and Magnus Ekengren observed "the EU has modest but promising capacities to assist member states overwhelmed by disaster...But these capacities do not suffice in the face of transboundary crises: threats that cross geographical and policy borders within the Union" (Boin, Rhinard, \& Ekengren, 2014, p. 131). Owing to its nature, transboundary crisis management requires international co-ordination and co-operation. However, they pointed out the European Union has limited capacities to facilitate a joint response to a transboundary threat confronting multiple member 
states. They found the "EU is still far removed from acting in an autonomous fashion in response to transboundary crises", although any future crises likely will provide some impetus to move to a more integrated approach (Boin et al., 2014, p. 140). These analysts supported the EU's adoption of a more active and explicit role in establishing a vision and a widely supported plan for transboundary crisis management.

In a review article published in Cooperation and Conflict, Paul 't Hart and Bengt Sundelius similarly aimed to call attention to the modern leadership challenges of crisis management, particularly with respect to increasing EU capacity to act quickly and cohesively ('t Hart \& Sundelius, 2013). Revisiting an agenda they proposed for European crisis management research and preparedness training a decade and a half earlier, they noted the "strategic use of fear has become part and parcel of our world" ('t Hart \& Sundelius, 2013, p. 445). Drawing on several of Boin et al.'s observations about the nature of transboundary crises, 't Hart and Sundelius offered European leaders eight updated recommendations for strengthening modern crisis management efforts (Boin \& Ekengren, 2009; Boin, Ekengren, \& Rhinhard, 2013; Boin, 't Hart \& McConnell, 2009). They noted that since their original agenda was formulated, international social science research on risk and crises has proliferated and so deepened governmental capacity in many states. However, they argued for more systematic study of EU crisis management practices, and more capacity to link and deploy experts and expertise to supply "instant" analytical support in times of great need ('t Hart \& Sundelius, 2013, p. 457).

So, the development and enrichment of the transboundary crises concept has been an innovative, helpful contribution to thinking about crisis leadership. School members carefully have studied several key aspects of the EU's emergency response capacities in light of the new crisis context, argued for more expert analysis on how to manage modern crises, and for more institutionalization of response capacity and decision co-ordination across the member states. Moreover, they convincingly argued for more institutionalized connections between and among researchers, bureaucrats and political decision-makers toward increasing the EU's crisis management capacity. As 't Hart and Sundelius concluded, the foreseeable future "will require timely and strong political leadership to ensure European governments, European businesses and responsible European institutions will not be caught unprepared...This is not a call for one further instance of Brussels' usurping national sovereignty. It is about developing a flexible capacity for joint problem-solving in the face of common, trans-boundary risk and threat affecting all Member States" ('t Hart \& Sundelius, 2013, p. 457).

In its scholarly publications since 2008 , the School has contributed in a few other areas to the study of crisis leadership. First, the evaluation of leaders has been engaged in three essays. The question of how to assess the exercise of leadership is one of the traditional narratives within the mainstream political leadership literature. However, though a risk management lens, the task takes on more complexity. In 2011 Paul 't Hart penned a short article on evaluating public leadership. He held "our expectations of leaders and leadership are embedded in our underlying ideas about good government" and these criteria have been subject to change in values, cultures and dominant coalitions ('t Hart, 2011, p. 324). For him, public leadership assessment rests on three discrete qualities that interrelate with each other: prudence, support and trustworthiness. ' $t$ Hart carefully connected good leadership to the community's need for safety and stability. He wrote that it "mobilizes collective wisdom, that elusive and intricate mix of analytical judgement, discernment, intuition and comprehension...Effective public leadership is about provoking, enabling, and protecting the work others need to do to enable the community as a whole to address their most significant challenges" ('t Hart, 2011, p. 326).

Two years later Arjen Boin, Sanneke Kuipers and Werner Overdijk published "Leadership in Times of Crisis: A Framework for Assessment" (Boin, Kuipers, \& Overdijk, 2013). They referenced 't Hart's 2011 essay, and asked how can leadership performance during a crisis be reasonably assessed? In light of the argument that crises pose ever more difficult challenges for bureaucracies, and that modern governance structures and cultures are not well designed to cope with radically novel situations, they set out to delineate what crisis leaders ought to do (Boin et al., 2013, p. 87) They proceeded to itemize the ten key tasks crisis management leaders face, including early recognition of threats, sense-making, orchestrating vertical and horizontal coordination, rendering accountability and enhancing organizational resiliency. In 2015 Annika Brändström authored an analysis of "Crisis Accountability: Ministerial Resignations in Sweden". She examined ten crisis events in Sweden to evaluate ministerial survival, and drew from Boin et al.'s $(2005,2010)$ work on blame management during crisis to support her study (Brändström, 2015, p. 307). All three of these articles helpfully underscore that public evaluations of effective crisis leadership rest heavily on the expectations of citizens and communities; there is no independent measure for judging good crisis leadership. So one lesson to be drawn from these analyses is that polities ought to decide for themselves what sorts of normative behaviors or actions they desire on the part of crisis managers. In this way, then, leaders who manage crisis may be assessed more clearly, consistently and fairly, without necessarily lapsing into blame game politics or impressionistic judgments about performance. 
A second area of research concerns information dissemination and crisis. Andrew Hindmoor and Allan McConnell focused analytic attention on why the warning signals of an impending financial crisis seemed to be ignored by political elites, treasury officials and financial regulators (Hindmoor \& McConnell, 2013, 2015). They noted "in the crisis and disaster literature, it is well accepted that failure is not the product of a single, context-free phenomenon. Rather, failure is the product of multiple individual, institutional and societal factors that coalesce in pathological ways" (Hindmoor \& McConnell, 2015, p. 66). They explored the nature of institutional signaling and retrospective evaluation to conclude key decision-makers, leaders, financial regulators and bank executives failed to spot evidence of the impending financial crisis in the UK. So in fact it was not easy or possible to anticipate the crisis that unfolded.

In a similar vein is a 2012 contribution from this school that merits attention. Titled "Prime Ministerial Rhetoric and Recession Politics: Meaning Making in Economic Crisis Management", it focused on how the UK, Irish and Australian prime ministers tried to publicly explain, assess and account for the global financial crisis and its consequences. In many respects this study compares with other essays focusing on crisis leadership and blame shifting as mentioned above. At the same time, it is quite unique in several ways. For example, the authors pointed out that although rhetorical perspectives on political leadership have a "Iong and venerable tradition," and crisis rhetoric has been intensively studied in the American case, this is not true for parliamentary systems (Masters \& 't Hart, 2012, p. 760). They concluded that, owing to systemic differences, prime ministers face more pressure to manage meaning and blame than their presidential counterparts. So, in the face of similar crisis conditions, leaders may face more complexity, or less, in responding to traumatic events owing to institutional factors. They suggested further comparative analysis will help to explain the mediating effects of institutional structures on leadership styles (Masters \& 't Hart, 2012, p. 775). This is a superb study that, along with the others reviewed above, nicely demonstrates how this School's authors have taken up some of the traditional research questions in the field of political leadership and produced innovative, fresh thinking about modern crisis leadership.

The influence of the School extends well beyond its stable of active authors. The sort of analysis it undertakes, and its particular success in revisiting some core questions about the nature of leadership within the modern context and from the perspective of crisis management, has led a few other analysts to till this particularly fertile field of scholarship. For example, in their 2015 study of how European political leaders made sense of the Euro Crisis, Femke van Esch and Marij Swinkels examined whether incorporating leaders' personality traits will increase understanding of how leaders interpreted the crisis context. This article adopted a deep textual analysis method to test its core hypothesis. Many of its key conceptualizations mirror those of the School, especially concerning what constitutes a crisis and why leaders engage in sense-making behavior (van Esch \& Swinkels, 2015, p. 1214). The Boin-'t Hart-McConnell approach to studying modern crisis leadership has provided an intellectually rich and credible foundation upon which to establish new research initiatives in this field of study.

\subsection{Decentralist Perspectives on Crisis Leadership}

All of the articles discussed to this point are rather state-centric in their focus. This is to say that they share, as Daniel P. Aldrich put it, a "single-minded focus on the state and the market as the core mechanisms for developing both disaster-resistant societies and recovery schemes" (Aldrich, 2011, p. 61). Our search for new scholarly treatments of political leadership under crisis revealed several analyses that merit recognition for their decentralist perspective. In a Policy and Politics article titled "Local Government and Structural Crisis: An Interpretive Approach", Kevin Orr suggested many analysts (including those within the School) remain uninterested in the underlying causes of crises or the structural context in which they occur (Orr, 2009, p. 40). Orr pointed out that local government, although often ignored in crisis treatments, is an important site for exploring crisis as it is a part of government that is particularly exposed to direct expressions of crisis (Orr, 2009, p. 44). ${ }^{1}$ He concluded that the UK case finds "leaders do not simply manage 'objective' crises, but may also choose to construct crises in order to pursue particular courses of action" (Orr, 2009, p. 52).

Orr's focus on crisis as a discourse that can be constructed and manipulated is similar to Benjamin Moffitt's treatise on "How to Perform Crisis: A Model for Understanding the Key Role of Crisis in Populism". Moffitt held "crises are never 'neutral' phenomena but must be mediated and 'performed' by certain actors" (Moffitt, 2015, p. 190). Rather than being external to populism, crisis should be acknowledged as a feature that is internal to populism. So, in a sense, "if we do not have the performance of crisis, we do not have populism" (Moffitt, 2015, p. 191). The notion that leaders address crisis through the prism of institutionally- bounded performance is explored in John Gaffney's study of "Political Leadership and the Politics of Performance: France, Syria and the Chemical Weapons Crisis of 2013". Gaffney concluded that the institution of the French presidency obliges its incumbent to

${ }^{1}$ For a clear and detailed account of the virtues of keeping crisis decision-making close to local authorities, see Shinoda (2013). 
be "on stage" permanently (Gaffney, 2014, p. 223).

The Orr, Moffitt and Gaffney studies exemplify an approach to crisis and political leadership that moves beyond considering crises as rather unidimensional exogenous shocks that must be managed by experts and politicians. Rather from their particular vantage points they inquire into the structure, and the structuring, of crisis events. Each author suggests that crises can influence the distribution of resources and power, and so precarious leadership contexts may be understood to have a subtle utility. In engaging crises leaders can gain, or lose, resources. And so in focusing on the deeper meaning of crisis events and their role in structuring community power, these studies are similar to another category of approach that appeared in our search: the heresthetics of crisis leadership.

In their study titled "Transforming Power Relationships: Leadership, Risk, and Hope", James H. Read and lan Shapiro examined how leaders manage to resolve chronic community conflict in cases such as the "Troubles" in Northern Ireland, and racial conflict in South Africa. These authors explored how leaders might undertake "strategically hopeful action" which is a certain kind of "calculated risk-taking in the face of imponderably complex circumstances" (Read \& Shapiro, 2014, p. 41). In their persuasive analysis of how leaders can initiate co-operation across divided communities, the authors referenced William Riker's work on heresthetics, or the "art of political manipulation" (Read \& Shapiro, 2014 , p. 46). Their treatment emphasizes that routine leadership cannot resolve deep conflict because ordinary political incentives simply reinforce the status quo (Read \& Shapiro, 2014, p. 52).

Riker's heresthetic approach was employed by Tim Heppell to study David Cameron's Conservative party. He suggested particularly that it is the transformation of the Conservatives from a state of "'systemic crisis' to stalling the realignment of the left and establishing a realignment of the right" that merits investigation (Heppell, 2013, p. 264). In a careful account, Heppell aimed to reveal the logic of Cameron's coalition deal with the Liberal Democrats and his effort to reconstruct the political centre in the United Kingdom. The author concluded that "the concept of heresthetics reminds us that political agency matters. It directs us toward the idea that skillful political leaders can outmaneuver political adversaries, can redefine political situations, can reframe policy options, can manipulate agendas and can change the process through which political debates and decisions are undertaken (Heppell, 2013 , p. 277). The Read and Shapiro study along with the Heppell analysis underscore that some kinds of crisis are not simply random, exogenous shocks. Crisis may originate in long simmering organizational fractures that foster deeply held animosities. Their resolution requires the skills of a master heresthetician to fundamentally change the underlying communal dy- namics for the benefit of the group. Therefore certain contexts may indeed require a specific sort of extraordinary leadership that lies beyond the crisis-resolution capacities of the state, the market and the ordinary exercise of power.

\subsection{Followership Studies}

Our search of the scholarly literature published in the wake of the global financial crisis revealed another kind of focus for leadership scholars: followers. Here analysts represent a variety of approaches and address quite different conundrums, yet there is an interesting commonality in their focus. For example, in 2011 Emiliano Grossman and Cornelia Woll inquired why the services directive proposed by Internal Market Commissioner Frits Bolkestein provoked such a backlash in France, as well as in Sweden, Belgium, Germany and Italy. They asserted their findings illustrate the importance of political leadership in institutional development, particularly vis-à-vis understanding resistance (Grossman \& Woll, 2011, p. 346). Although France consistently has scored highest on economic fear measures since the early 2000s, they concluded the virulent reaction to the Bolkestein directive was rooted in a leadership crisis within the Socialist Party (Grossman \& Woll, 2011, p. 360).

Geoffrey Evans and Kat Chzhen also focused on public reaction to the GFC and a decline in leader reputation to explain voters' defection from the British Labour party. After examining individual-level panel data to compare possible explanations, they concluded that, despite its magnitude and global significance, the 2008 financial crisis had a limited impact on the 2010 election in part because the event was not specific to Britain. So the attribution of responsibility could therefore be broadened (Evans \& Chzhen, 2013, p. 9). Neil Robinson, in a paper titled "Russia's Response to Crisis: The Paradox of Success", underscored Russia's experience with the GFC was unusual: after the event's initial, deep impact the economy recovered relatively quickly. Russia did not plunge into recession for as long as some other countries. Echoing the Evans and Chzhen findings, Robinson noted extant treatments assume incumbent governments are less likely to be blamed by their citizenry when economic shocks are exogenous, as in the case of the GFC (Robinson, 2013, p. 451). However, in the Russian case, citizens perceived the economy was recovering without getting better even though economic growth returned in 2009. He found this view arose partly because the financial crisis was seen as a manifestation of deeper problems and that a recovery that failed to deal with these problems was perceived to lack worth (Robinson, 2013, p. 469). So, leaders' miscommunications and strategic errors worked to perpetuate citizens' sense of economic dislocation long after the recovery had begun. 
These three studies helpfully signal how the literature is evolving. First, and importantly, all three clearly are concerned to understand and explain public views and reactions. This is a welcome and necessary counterweight to a strong tendency among leadership scholars to focus on the decision-makers and ignore followers (Kellerman, 2008). Second, these three studies share a common interest in exploring how citizens respond to change, whether change appears as a longterm political transformation or as an unpredictable but significant financial shock. There is great need for more understanding of followers' roles and responsibilities with respect to change and crisis leadership.

\section{Discussion}

So, in considering scholarly analyses of political leadership and crisis topics that have been published from 2009 to the end of 2015, we located a significant number of works that adopt a centralist perspective, and are associated with three scholars in particular: Arjen Boin, Paul 't Hart and Allan McConnell. We chose to group them into one category (the Boin-'t HartMcConnell School) and reviewed the main areas of focus and some new lines of inquiry. As the relative size of the collection suggests, this is a burgeoning literature that is producing many new insights into public leadership in the modern crisis context. The School's common method of approaching the subject-as an exercise in crisis management-is helpful in terms of building a unified understanding across many sorts of cases and particular topics. At the same time the method is limited owing to its tendency to treat the crisis condition as an exogenous problem-with a clear beginning and ending-that central decision-makers must address. As well, the works reviewed here tend to place much more emphasis on the leaders and their strategic behavior rather than on the publics. This approach's strengths lie in its insight into analyzing how political leaders and decision makers ought to act once a crisis appears.

In contrast with this centralist approach, we discern a second grouping of studies that are common in their decentralist perspective. Kevin Orr's interpretive approach to local government and structural crisis highlights that many analyses of crisis leadership largely ignore the underlying causes of crises and the structural context in which they occur. Moreover, because local governments often are the first responders to many sorts of crisis, and because they are a usual contact point between the community and government, they offer an excellent locale for the study of crisis leadership. Benjamin Moffitt (2015) and John Gaffney's (2014) considerations of crisis performance nicely complement the articles by Tim Heppell (2013), and James Read and Ian Shapiro (2014), although this may not be apparent at first blush. The authors are com- mon in their understanding of crises as social situations that are structured by the populations that participate in them. Leaders, as Read and Shapiro (2014) and Tim Heppell (2013) remind us, sometimes can exercise extraordinary agency and restructure a divided and difficult social environment toward the common good.

Our review reveals clear interest in studying how followers respond to crisis contexts, and how they interpret leaders' messaging and cues. The case of the French backlash to the Bolkestein directive underscores the pivotal role micro-institutional dynamics like internal party strife can play in large-scale change processes. It is interesting to note that Evans and Chzhen (2013) find the international significance of the 2008 financial crisis probably insulated politicians from electoral repercussions because responsibility for it could be attributed to events beyond Britain's borders. However, in the Russian case citizens remained critical of their leaders' economic management capacity long after the relatively mild effects of the recession dissipated. These studies aim in part to explain how followers react and respond to crisis contexts. They illustrate the complexity of crisis leadership and also the opportunity for further research into communication flows between leaders and the led. In their attention to citizens' responses and to probing the structural aspects of crises, these authors contribute rich and helpful insights, and it is instructive to reconsider the literature delineated in the first grouping in light of the complex issues raised by the authors in the second and third grouping.

Moving our focus from the narrow analysis of the three groupings discussed above toward a broader consideration of the 26 articles as a single body of work, we think it's helpful to point out there are several disagreements among the authors about the nature of crisis and the current political context. Concerning the nature of crisis, there are a variety of views. Many of the authors reviewed here consider crises simply as random, unpredictable events that are part and parcel of the normal socio-economic environment, and there is merit in this view. While there is no doubt that events of 9/11 were important, this was not the first time the United States experienced terrorism, nor was it the first time al-Qaeda attacks resulted in the death of Americans. Likewise, while the GFC had a tremendous impact on the global economy, so did the bursting of the "dot com bubble" in 2000 as well as the Asian, Russian and Mexican financial crises of the 1990s. Conducting crisis research based on the premise that each catastrophe intrinsically is novel certainly runs the risk of merely putting old wine in new bottles. At the same time, some scholars firmly engage the position that there are different kinds of crises and that new types of crises can develop. Moreover, a few advance the view that some sorts of crises may be more challenging than others to manage because they are more trenchant 
(see for example Read \& Shapiro, 2014) or owing to their unusual nature. The conceptualization of transboundary crisis is a good example of the latter approach (e.g. Boin \& Rhinhard, 2008).

Within the body of work on crisis leadership, scholars disagree as well whether the political context has changed or remained the same. For many analysts, the larger environment within which leadership occurs is much the same as it was before 9/11. In other cases, scholars hold that the current context profoundly has changed. Owing in part to large-scale social, economic and technological change, modern political leaders operate in a different, less secure and less stable decisionmaking environment than their predecessors. In this view, incremental change and enduring institutional stability seem to be antiquated markers of an earlier period. As a consequence the necessity to engage in crisis management has become more central to leadership behavior, as many analysts within the School hold. For our part, we think such debate about the nature of modern crises, and the current context within which crisis leadership occurs, present exciting avenues for new investigations and necessary analysis.

As a final comment on the body of work we have reviewed here, although we located many excellent studies in the period under review that adopted a variety of methods and perspectives, we were surprised that one paradigm in particular largely has not been taken up by crisis leadership scholars: the VUCA approach. The notion of VUCA originally was introduced by the US Army War College to describe the world following the collapse of the Soviet Union: volatile, uncertain, complex and ambiguous (Casey, 2014, p. 75). It was not until the $9 / 11$ attacks that it gained attention for its utility in describing a new leadership environment. As Lawrence (2013) explains, the acronym captures fours aspects of the precarious contexts surrounding modern leaders. The "V" stands for volatility, which is understood to mean the nature, speed, volume and magnitude of unpredictable change. The " $U$ " represents uncertainty. Uncertainty is a product of volatility, and it confounds efforts to make decisions, and accurately predict results. Within the VUCA acronym, " $C$ " stands for complexity, and represents numerous causes and mitigating factors involved in a problem. Finally, the " $A$ " indicates the ambiguity resulting from a lack of clarity about the meaning of an event which is held to be symptomatic of modern decision-making contexts (Lawrence, 2013, p. 6). Since its creation, several authors have written about VUCA from the perspective of business management, executive development and organizational management (for example Rodriguez \& Rodriguez, 2015). However, in our search at least, this approach has not yet been clearly adopted by leadership scholars. Given the leadership literature's well demonstrated capacity to borrow from other disciplines, it is somewhat surprising that the VUCA view remains rather undeveloped. This paradigm may be a useful one to pursue for those who hold we are in a new crisis context, particularly because it assumes the current political context represents a new, more precarious reality that is marked by endemic instability and the necessity for perennial crisis management on the part of elites.

\section{Conclusion}

Our understanding of leadership and its evaluation necessarily is grounded in our times and our social context. The resurgence of scholarly interest in studying political leadership is a welcome trend. However, the 9/11 attacks seemed to introduce a new precariousness into the modern leadership context, and the 2008 global financial crisis seemed to confirm that modern political leaders regularly face traumatic and destabilizing events, and are expected to manage them skillfully. To survey how political leadership is being studied since 2008, we identified recent work published from January of 2009 to December of 2015. We carefully examined 26 academic articles that focused on political leadership and crisis, and identified a significant amount of new scholarship in this area. The literature has been enriched by contributions from three leading scholars who, along with their associates, have contributed many excellent insights through studying traditional leadership questions via a crisis management perspective.

As well, there is a cluster of scholars whose work conceptualizes crises as complex, decentralized, multidimensional phenomena. Finally, our examination found promising new work on the response of followers to leaders' behaviors and signals. Understanding when and how followers accept, resist or misinterpret leaders' signals certainly is fundamental to the study of leadership. These analyses probe some of the opportunities for deep change that crises present, and demand. In the works reviewed here, analysts disagree about whether modern crises might be different than earlier ones, and whether the modern political environment has shifted fundamentally in the last fifteen years. At the same time, most of the scholarship affirms modern political leaders retain much capacity to respond to crises, manage their effects, demonstrate agency and adapt to new decision-making environments.

\section{Acknowledgments}

We sincerely thank the Journal's anonymous reviewers and diligent editors for helpful comments and suggestions.

\section{Conflict of Interests}

The authors declare no conflict of interests. 


\section{References}

Aldrich, D. P. (2011). Between market and state: Directions in social science research on disaster. Perspectives on Politics, 9(1), 61-68.

Allison, G. (1971). Essence of decision: Explaining the Cuban missile crisis. Boston: Little, Brown.

Bailey, F. G. (1988). Humbuggery and manipulation: The art of leadership. Ithaca, NY: Cornell University Press.

Boin, A. (2009). The new world of crises and crisis management: Implications for policymaking and research. Review of Policy Research, 26(4), 367-377.

Boin, A., \& Ekengren, M. (2009). Preparing for the world risk society: Towards a new security paradigm for the European Union. Journal of Contingencies and Crisis Management, 17(4), 285-294.

Boin, A., Ekengren, M., \& Rhinard, M. (2013). The European Union as crisis manager: Problems and prospects. Cambridge: Cambridge University Press.

Boin, A., Kuipers, S., \& Overdijk, W. (2013). Leadership in times of crisis: A framework for assessment. International Review of Public Administration, 18(1), 79-91.

Boin, A., McConnell, A., \& 't Hart, P. (2008). Governing after crisis: The politics of investigation, accountability and learning. Cambridge: Cambridge University Press.

Boin, R. A., Preston, T., 't Hart, P., \& McConnell, A. (2010). Leadership style, crisis response and blame management: The case of hurricane Katrina. Public Administration, 88(3), 706-723.

Boin, A., \& Rhinard, M. (2008). Managing transboundary crises: What role for the European Union? International Studies Review, 10(1), 1-26.

Boin, A., Rhinard, M., \& Ekengren, M. (2014). Managing transboundary crises: The emergence of European Union capacity. Journal of Contingencies and Crisis Management, 22(3), 131-142.

Boin, A., 't Hart, P., \& McConnell, A. (2009). Crisis exploitation: Political and policy impacts of framing contests. Journal of European Public Policy, 16(1), 81106.

Boin, A., 't Hart, P., Stern, E., \& Sundelius, B. (2005). The politics of crisis management: Public leadership under pressure. Cambridge: Cambridge University Press.

Brändström, A. (2015). Crisis accountability: Ministerial resignations in Sweden: Crisis accountability. Scandinavian Political Studies, 38(3), 301-320.

Burns, J. M. (1978). Leadership (1st ed.). New York: Harper \& Row.

Casey, G. W., Jr. (2014). Leading in a 'VUCA' world. Fortune, 169(5), 76-77.

Cole, A. (1994). Studying political leadership: The case of François Mitterand. Political Studies, 42(3), 453-468.

Edelman, M. J. (1988). Constructing the political spectacle. Chicago, IL: University of Chicago Press.

Elgie, R. (1993). The role of the prime minister in France,
1981-1991. London: Palgrave Macmillan.

Evans, G., \& Chzhen, K. (2013). Explaining voters' defection from Labour over the 2005-10 electoral cycle: Leadership, economics and the rising importance of immigration. Political Studies, 61(1), 3-22.

Gaffney, J. (2014). Political leadership and the politics of performance: France, Syria and the chemical weapons crisis of 2013. French Politics, 12, 218-234.

Grossman, E., \& Woll, C. (2011). The French debate over the Bolkestein directive. Comparative European Politics, 9(3), 344-366.

Heppell, T. (2013). The conservative party leadership of David Cameron: Heresthetics and the realignment of British politics. British Politics, 8(3), 260-284.

Hindmoor, A., \& McConnell, A. (2013). Why didn't they see it coming? Warning signs, acceptable risks and the global financial crisis. Political Studies, 61(3), 543560.

Hindmoor, A., \& McConnell, A. (2015). Who saw it coming? The UK's great financial crisis. Journal of Public Policy, 35(1), 63-96.

Kellerman, B. (2008). Followership: How followers are creating change and changing leaders. Boston, MA: Harvard Business Press.

Knight, F. H. (1971). Risk, uncertainty and profit. Chicago, IL: University of Chicago Press.

Kuipers, S., \& Boin, A. (2015). Exploring the EU's role as transboundary crisis manager: The facilitation of sense-making during the Ash crisis. In R. Bossong \& H. Hegemann (Eds.), European civil security governance: Diversity and cooperation in crisis and disaster management. Basingstoke: Palgrave Macmillan.

Lawrence, K. (2013). Developing leaders in a VUCA environment. Chapel Hill, NC: Kenan-Flagler Business School.

Masters, A., \& 'T Hart, P. (2012). Prime ministerial rhetoric and recession politics: Meaning making in economic crisis management. Public Administration, 90(3), 759-780.

Moffitt, B., (2015). How to perform crisis: A model for understanding the key role of crisis in contemporary populism. Government and Opposition, 50(2), 189217.

Mueller, D. C. (2001). The importance of uncertainty in a two-stage theory of constitutions. Public Choice, $108(3 / 4), 223-258$

Orr, K. (2009). Local government and structural crisis: An interpretive approach. Policy \& Politics, 37(1), 39-55.

Read, J., \& Shapiro, I. (2014). Transforming power relationships: Leadership, risk, and hope. American Political Science Review, 108(1), 40-53.

Rhinard, M., \& Boin, A. (2009). European homeland security: Bureaucratic politics and policymaking in the EU. Journal of Homeland Security and Emergency Management, 6(1), 50-17.

Robinson, N. (2013). Russia's response to crisis: The paradox of success. Europe-Asia Studies, 65(3), 450-472. 
Rodriguez, A., \& Rodriguez, Y. (2015). Metaphors for today's leadership: VUCA world, millennial and "cloud leaders". The Journal of Management Development, 34(7), 854-866.

Shinoda, T. (2013). DPJ's political leadership in response to the Fukushima nuclear accident. Japanese Journal of Political Science, 14(2), 243-259.

't Hart, P. (2011). Evaluating public leadership: Towards an assessment framework. Public Money \& Management, 31(5), 323-330.

't Hart, P., \& Sundelius, B., (2013). Crisis management revisited: A new agenda for research, training and capacity building within Europe. Cooperation and Conflict, 48(3), 444-461.

Thomson Reuters. (2016). Discover web of science. Web of Science. Retrieved from http://wokinfo.com/cita tionconnection

van Esch, F., \& Swinkels, M. (2015). How Europe's political leaders made sense of the euro crisis: The influence of pressure and personality. West European Politics, 38(6), 1203-1225.

\section{About the Authors}

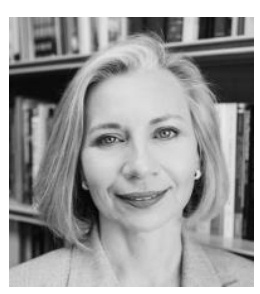

Cristine de Clercy is an Associate Professor in Political Science at Western University in London, Canada. She is a director of the Leadership and Democracy Laboratory, and the LEADR Research Group. Dr. de Clercy specializes in studying leadership, and how political leaders address uncertainty and complexity. Her new work includes a study of uncertainty and the American constitution (in L. M. Imbeau and S. Jacob (eds.) Behind a Veil of Ignorance? Power and Uncertainty in Constitutional Design, Springer 2015), and a study of party discipline within Canada's House of Commons.

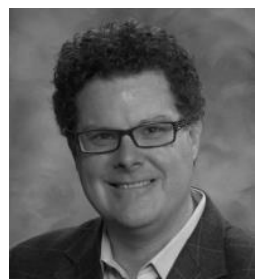

Peter A. Ferguson is an Assistant Professor in Political Science at Western University. He is a Director of the Leadership and Democracy Laboratory. Dr. Ferguson specializes in comparative politics, particularly democratic transitions and democratic stability in the developing world. He has authored a book on the stability of democratic regimes and the role of democratic uncertainty in explaining reversions (titled Undertow in the Third Wave) which is in review. His new work concerns research on political risk assessment mitigation strategies. 